\title{
EMPEROR AVITUS IN PANNONIA?
}

\author{
PÉTER KOVÁCS
}

\author{
Pázmány Péter Catholic University \\ Egyetem Str. 1, H-2081 Piliscsaba, Hungary \\ kovacs.peter@btk.ppke.hu
}

\begin{abstract}
In his paper the author examines the sources of the supposed Western Roman military expedition of Emperor Avitus in Pannonia in 455 that was thought to be the last Roman military action in the territory of the former Roman province. Analizing the sources, he comes to the conclusion that during his short reign, Avitus had no time to visit the province and his route (iter) mentioned by Sidonius Apollinaris must be identified with his journey from Arelate to Rome. The Roman military action in Pannonia can probably be identified with a short demonstrative campaign in the SW region of the dioecesis (i.e. Savia) or with a legation of the Pannonian Barbarians to the emperor in Northern Italy.
\end{abstract}

Keywords: the history of Pannonia in $5^{\text {th }}$ century, Roman Pannonia, Emperor Avitus, Sidonius Apollinaris

One of the last episodes of late Roman Pannonia was - according to several theories - that Emperor Avitus would have visited Pannonia in 455-456 AD and regained the control of the provinces after Attila's death and the battle of Nedao in $454 .{ }^{1}$ Some scholars even tried to localize it exactly, and the last Roman period of the inner fort of Keszthely-Fenékpuszta had been connected to this event. ${ }^{2}$ As the fort was interpreted as a supply base of Avitus they identified its final destruction layer and mass graves with an unknown siege of the Ostrogoths who arrived at the province in the following year. ${ }^{3}$ Despite these opinions, in my paper I intend to deal with this supposed imperial visit, and first of all, with its sources.

${ }^{1}$ ANDERSON 1936, 168-169, n. 3; SEECK 1896, col. 2396; BugIANI 1909, 90-91; SEECK 1921, VI, 328-329; ALFÖLDI 1925, 123; AlFÖldi 1926, 91, 100; SCHMIDT 1927, 459; ENSSLIN 1927-1928, 153-154; SCHMIDT 1941, 262, 269; Stein 1959, 369; MócSy 1962, col. 582; LOYEN 1967, 57-58, VÁRADY 1969, 291-292, 331-332, 399-402; MAENCHEN-HELFEN 1973, 144-147; BóNA 1973, 306-307; Mócsy 1974, 351; Wolfram 1979, 324; Demougeot 1979, 577; MATHISEN 1981, 237-240; ZeCCHINI 1983, 297; LACAM 1986, 147 160; Régészeti kézikönyv, 51; BÓNA 1991, 114-115; SCHWARz 1992, 51-52; KISS 1999, 112-117; WIRTH 1999, 47, 119; LOTTER 2003, 19-20, 106, Anm. 183, 157, Anm. 589; GraČANIN 2006, 57; Siebigs 2010, 912-913; ANDERS 2010, 500-505; GRAČANIN-ŠKRGULJA 2014, 170-171; GrZYWACZWSKi 2014, 183; Hughes 2015, 247-248; BATTAGLIA 2017, 29, 131, n. 512
2 BÓNA 1969, 279; SÁGI 1970, 156; BÓNA 1973, 306-307; MATOLCSI 1974; FÜZES 1978; BÓNA 1984, 289; MÜLleR 1987, 108 109; SÁGI 1989, 292-294; KISS 1999, 112-117; R. MüLLER: Hunok, germánok [Huns and Germans]. In: Évezredek üzenete a láp világából. Régészeti kutatások a Kis-Balaton területén 1979-1992. Zalaegerszeg 1996, 96; STRAub 2002

${ }^{3}$ Based on the new correct evaluation of the finds the destruction layer must be connected to the incursion of the Sarmatians and Quadi in 374: O. HeInRICH-TAmÁsKa: Keszthelv-Fenékpuszta zwischen Spätantike und Karolingerzeit. In: Die Langobarden. Das Ende der Völkerwanderung. Katalog zur Ausstellung im Rheinischen LandesMuseum Bonn, 22.8.2008-11.1.2009. Hrsg.: M. Hegewisch. Bonn 2008, 99-100; R. MüLLER: Mikor épült a keszthely-fenékpusztai késő római kori erőd? (Wann würde die spätrömische Festung von Keszthely-Fenékpuszta erbaut?). MFMÉ 12 (2011) 147-148; HEINRICH-TAMÁSKA-MÜLLER-STRAUB 2012, 37. 
Concerning Avitus' Pannonian visit only one single written source exists, a panegyric, written and presented by Sidonius Apollinaris to the emperor, his father-in-law, on the occasion of his consulship in Rome on 1 January $456 .{ }^{4}$

Sidonius Apollinaris Carm. VII.588-591 hic tibi restituet Libyen per vincula quarta, / et cuius solum amissas post saecula multa / Pannonias revocavit iter, iam credere promptum est / quid faciat bellis.

'He shall restore Libya to thee a fourth time in chains - and when a man has recovered the lost Pannonias after so many generations by a mere march, 'tis easy to feel sure even now of what he can do by waging war' (translation by B. W. Anderson).

In the latter passage of the panegyric (lines 585-598), the poet depicted Avitus' anticipated victories, mainly a success against the Vandals. ${ }^{5}$ These were illustrated by the emperor's march/route (iter) that recovered the province. Examining the text, it becomes clear that there was no fight and the success was achieved only (solum) by the route itself.

The supposed event can be dated exactly as it surely happened between the elevation of Avitus at Arelate (9 July 455) and the presentation of the panegyric (1 January 456), most probably after 21 September when Avitus entered Italy. Several written sources are available concerning his short reign in 456 (15 months: cf. Chron. Gall. 625 Chron. min. I p. 664). His Pannonian visit cannot be supposed to happen in this year because Avitus had no opportunity to leave Rome and visit Pannonia (and it should have lasted at least three months). During his reign he stayed constantly in Rome and he had to deal with several much more serious problems than Pannonia. Despite his attempts, he was never recognized by East Rome, the Vandals attacked Sicily and Corsica, there was a famine in Rome, he could hardly pay his Gaulish Barbarian mercenaries, he had to send him back. From the very beginning, he was very unpopular in Rome and in the senate that finally revolted against him. ${ }^{6}$ Based on these Avitus' supposed Pannonian visit (if ever existed) should be dated between September and December 455.

The following dates are available concerning Avitus' reign.

\begin{tabular}{|l|l|l|l|}
\hline \multicolumn{1}{|c|}{ Event } & \multicolumn{1}{|c|}{ Date } & \multicolumn{1}{c|}{ Location } & \multicolumn{1}{|c|}{ Source } \\
\hline Imperial acclamation & 9 July 455 & Arelate & Chron. min. I p. 304 \\
\hline Entering Italy & 21 September 455 & Rome & Chron. min. I p. 304 (Italiam ... ingressus XI $k$. Oct.) \\
\hline Consulship & 1 January 456 & Rome & Sid. Ap. VII,7-13, 600-602, Chron. min. I p. 247, 490, 4927 \\
\hline Ricimer's successes against the Vandals & Spring of 456 & $\begin{array}{l}\text { Agrigentum, } \\
\text { Corsica }\end{array}$ & $\begin{array}{l}\text { Hydat. 176, 177 Chron. min. II p. 29, Sid. Apoll. Carm. II,353, 367; } \\
\text { Prisc. Frag. 31.1 }\end{array}$ \\
\hline $\begin{array}{l}\text { Discharing his Gaulish troops from Rome } \\
\text { because of the famine }\end{array}$ & Summer of 456 & Rome & Ioann. Ant. Frag. 202.1 \\
\hline Revolt, escaping from Rome to Gaul (?) & Late summer of 456 & Gallia & Ioann. Ant. Frag. 202.2, Hyd. 177 \\
\hline Remistus' defeat & 17 September 456 & Ravenna & Chron. min. I p. 304 \\
\hline $\begin{array}{l}\text { Avitus was deposed by Ricimer } \\
\text { Avitus' death? }\end{array}$ & 17 October 456 & Placentia & $\begin{array}{l}\text { Chron. min. I p. 304, Theoph. AM 5948 } \\
\text { Ioann. Ant. Frag. 202.2, Chron. min. I p. 664, } \\
\text { but according to Greg. Tur. II.11, Eugr. II.7, Jord. Get. 240, Chron. } \\
\text { min. I p. 304, II p. 30, 186, 232 he was executed later in 457. }\end{array}$ \\
\hline
\end{tabular}

The route mentioned in the text as already Anderson observed must be identified with Avitus' journey from Arelate to Rome (another is unattested before his escape from Rome), ${ }^{9}$ and he entered Italy on 21 September (Auctar. Prosp. Haun. 7 Chron. min. I p. 304), therefore he could reach Rome at the beginning of October, as the earliest. ${ }^{10}$ Avitus could choose a shorter and faster continental route along the seashore (cca. $880 \mathrm{~km}$ ) and a longer

${ }^{4}$ LOYEN 1967; HARRIES 1994, 75-81; WATSON 1998; FurbetTA 2014; GRZYWACZWSKI 2014; BATTAGLIA 2017.

${ }^{5}$ For the fourth captivity, i.e. $4^{\text {th }}$ Punic war see D. Álvarez JIMÉNEZ: Sidonius Apollinarius and the fourth Punic war. In: New Perspectives on Late Antiquity. Ed.: D. Hernández de la Fuente. New Castle 2011, 158-172.

${ }^{6}$ For Avitus' reign see SEeCK 1896; Demougeot 1979, 576580; Mathisen 1981; Mathisen 1985; LaCAM 1986, 135-200; BuRgess 1987; MATHISEN 1991; HARRIES 1994, 54-81; Hughes 2015, 226-283.

Acta Archaeologica Academiae Scientiarum Hungaricae 71, 2020
${ }^{7}$ R. S. Bagnall-A. Cameron-S. R. SchwartZ-K. A. WorP: Consuls of the Later Roman Empire. Philological monographs of the American Philological Association 36. Atlanta/Georgia 1987, 446.

${ }^{8}$ Mathisen 1985; Burgess 1987; Mathisen 1991.

${ }^{9}$ ANDERSON 1936, 168-169, n. 3.

${ }^{10}$ Mathisen 1985, 234. 
(cca. $1450 \mathrm{~km}$ ), but more probable one was via Augusta Taurinorum-Mediolanum-Placentia-Ravenna in order to assure North-Italian capitals Mediolanum and Ravenna. Probably this time Avitus left his officer Remistus with troops (PLRE II, Remistus) at Ravenna (Chron. min. I p. 304). Both routes needed at least 45-60 days travel-time. ${ }^{11}$ Why did not he leave immediately after his elevation Arelate? His only probable reason was that he needed time to organize suitable troops for his travel and he wanted to appoint new, Gaulish officials and made a pact with the king of the Goths, Theoderic II in order to avoid the Suebian danger in Hispania (Cf. Sid. Ap. Carm. VII.475-580, esp. 510-518 and 520-521, Hyd. 163, 170, 173). ${ }^{12}$ During his journey Avitus could hardly make a detour in Pannonia as he had to hurry to Rome. However the senate probably acknowledged him in his absence as emperor (Hyd. 166 a Romanis et evocatus et susceptus fuerat imperator) (probably this date is given in Victor Tunnunensis' work: 5 August (Chron. min. II p. 186); because of his Gaulish origin Avitus remained very unpopular in Rome and in the senate as well (that is why significant Gaulish and Goth troops followed him cf. Greg. Tur. II.11, Ioan. Ant. Frag. 202). ${ }^{13}$ His elevation could become complete only in Rome before the senate as the expression praesumptus honor mentioned in one of the continuations Prosper Tiro's Chronicon, based on the Consularia Italica (Continuatio Hauniensis Prosperi) clearly shows (Chron. min. I p. 304). Hydatius mentioned his route to Rome as follows: 163 Romam pergit et suscipitur. As Sidonius Apollinaris or another source omit to mention where Avitus exactly entered Italy but the suggested ${ }^{14}$ route via Noricum or Pannonia must surely be excluded as a route Arelate-NoricumPannonia-Rome is unattested. During his route, Avitus probably stopped at Mediolanum as Lacam suggested, but a Pannonian detour seems to be improbable. ${ }^{15}$

In view of this, the emperor never visited Pannonia or any other province of dioecesis Illyricum, Avitus as Aetius' officer fought much earlier in Noricum (lines 232-233). ${ }^{16}$ On the other hand, Mathisen correctly came to the conclusion that the plural Pannoniae used by Sidonius Apollinaris could concern the other provinces of WestIllyricum. ${ }^{17}$ For instance, Savia, Noricum mediterraneum had a special role in the defence of Italy and the Alps and one of Avitus' commanders could make a detour in this direction in order to confirm the claustra Alpium that signifcantly weakened during Attila's Italian campaign in $452 .{ }^{18}$

Latter event could confirm the Roman authority in the region that never belonged to the Huns and local Barbarian nominally acknowledged the Roman rule (based on a new foedus?). This success could have been mentioned in the panegyric. The revocatio Pannoniarum, establishing the Roman rule in entire Pannonia was naturally Sidonius Apollinaris' poetice exaggeration but the use of the plural Pannoniae can mean that at least two provinces of dioecesis Pannonia, Savia and the Norican provinces (?) were recovered.

What could be the reasons Avitus' activity in Western Illyricum?

1. First of all, as a new emperor he had to prove his abilities as supreme commander of the Roman army. ${ }^{19}$

2. After Nedao, a power vacuum is formed in Pannonia that the Gepids in Transylvania could not and did want to fill.

3. Another factor must also be considered: Marcellinus, ${ }^{20}$ comes Illyrici (PLRE II, Marcellinus 6) backed by Constantinople revolted against the western rulers after Aetius' death (Proc. Bell. Vand. I.6.7), and he did not acknowledge Avitus' reign either. Because of this fact, Avitus had to secure main continental roads leading from Italy to Constantinople..$^{21}$

4. The next point is that Avitus intended to recognize his rule with East Rome. His attempts (legation: Hyd. 166, coin minting in Marcianus' name: RIC 10 (1994) 2303-2305 and p. 181), according to his propaganda were successful (Hyd. 169), but Marcianus most probably never recognized him (cf. his consulship was not recognized

${ }^{11}$ I used the Roman route planner: http://orbis.stanford.edu.

${ }^{12}$ LACAM 1986, 136-142; Hughes 2015, 241-245.

${ }^{13}$ LACAM 1986, 143-146; HugHeS 2015, 247.

${ }^{14}$ Bugiani 1909, 90-91.

${ }^{15}$ LACAM 1986, 155-156.

${ }^{16}$ GraČANIN-ŠKKRGULJA 2014, 170.

${ }^{17}$ MATHISEN 1981.

${ }^{18}$ MaEnCHEN-HeLfen 1973, 146-147, who compared the event to Majorian's action (collecting troops) in 459 in the Danube region.

${ }^{19}$ So Bugiani 1909,91
${ }^{20}$ If the coniuratio Marcell(i)ana in Gaul in 457 concerns his person (Sid. Ap. Ep. I.11.6) he was also suitable for reign. On the other hand, the identification is at least dubious: G. E. MAX: Political intrigue during the reigns of the Western Roman Emperors Avitus and Majorian. Historia 28 (1979) 225-237; R. W. MATHISEN: Resistance and reconciliation: Majorian and the Gallic aristocracy after the fall of Avitus. Francia 7 (1979) 597-627; ZeCCHINI 1983, 295-299; MacGeorge 2002, 28-29.

${ }^{21}$ MacGeorge 2002, 15-67; Hughes 2015, 248.

${ }^{22}$ Mathisen 1981, 237-240; LACAM 1986, 148-160.

Acta Archaeologica Academiae Scientiarum Hungaricae 71, 2020 
in East, never promulgated laws together, coins were not minted in eastern mints in Avitus' name). Avitus probably tried diplomatically to solve the disputes situation of Illyricum between East and West. ${ }^{22}$ This could have been followed by a demonstrative campaign of a part of his army. Based on the treaty concluded in 424, realized in 437 following Valentinian's and Eudoxia's marriage (Cassiodorus Var. XI.1.9, Jord. Rom. 329), a part of West Illyricum, probably only Pannonia II came to the jurisdiction of Constantinople (cf. Attila occupied Sirmium during a war against East Rome in 441: Prisc. Frag. 11.1 and 2, Iust. Nov. XI.1-2, Hierocles Synecdemus c. XIX, Not. ep. eccl. Const. 13,848). ${ }^{23}$ The Goths were settled down into Pannonia in 456 following a foedus with Marcianus in territory of Pannonia I, II and Valeria (Jord. Get. L.264, LII.268, 270, 272). ${ }^{24}$ In the former passage, Jordanes geographically described Pannonia, its boundaries and cities. The author used several late antique geographic works (esp. Rav. Geogr. IV.19, Dim. prov. 18, Oros. I.2.27, Cosm, II.27), but he mentioned only nearest and the furthermost cities of the province in the point of view of Constantinople, Sirmium and Vindobona: Ornata patria civitatibus plurimis, quarum prima Syrmis, extrema Vindomina. His description has nothing to do with the new home-land of the Goths that he described separately: 268 qui in Pannonia sub rege Valamir eiusque germani Thiudimer et Videmir morabantur, quamvis divisa loca, consilia tamen unita (nam Valamer inter Scarniungam et Aqua nigra fluvios, Thiudimer iuxta lacum Pelsois, Vidimer inter utrosque manebant. Their land lay between the lacus Pelso/Balaton in Pannonia I and two rivers, the Scarniunga and the Aqua nigra in Valeria or Pannonia II (both are unidentifiable as they are not antique hydronyms, the former is clearly German name ${ }^{25}$ that show the lack of Roman provincial population in Valeria). It cannot be accidental that Eugippius later localized the Goths in Pannonia inferior: Eug. v. Sev. 5.1 Rugorum siquidem rex, nomine Flaccitheus, in ipsis regni sui coepit nutare primordiis habens Gothos ex inferiore Pannonia vehementer infensos, quorum innumera multitudine terrebatur. That is why Goths could have fought against the Sadages/Sadagarii, qui interiorem Pannoniam possidebant (Jord. Get. LIII.272). ${ }^{26}$ Pannonia secunda was included into the Gothic rule as the easternmost Pannonian town, Bassiana was defended by the Goths against the Hun siege (LIII.272 venientesque ad Basianam Pannoniae civitatem eamque circumvallans fines eius coepit praedare. 273 Quod conperto Gothi ibi, ubi erant, expeditionemque solventes, quam contra Sadagis collegerant, in Hunnos convertunt et sic eos suis a finibus inglorios pepulerunt). The continuation of Jordanes' account dealing with the Dalmatian incursion of the Suebi is more interesting: 273 Quiescente vero tandem Hunnorum gente a Gothis Hunumundus Suavorum dux dum ad depraedandas Dalmatias transit, armenta Gothorum in campis errantia depraedavit, quia Dalmatia Suaviae vicina erat nec a Pannonios fines multum distabat, praesertim ubi tunc Gothi residebant. Latter passage clearly shows that the land of the Goths was in the near of Dalmatia and Suavia, that proves, originally, Savia was not included in Marcianus' foedus with the Goths ${ }^{27}$ but the Hunimundus' Suebians did not live in province as the returning Suebi were defeated by the Goths by the Balaton (LIV.274) and the Danube (LV.280). Based on this fact, already Schmidt and others suggested Avitus' role in the new treaty but Jordanes did not mention the western ruler. Avitus' route mentioned by Sidonius Apollinaris cannot be identified with a legation of the Goths who would have met the emperor at Mediolanum. ${ }^{28}$ On the other hand, it cannot be ruled out that other Barbarians living in Noricum or Savia as the Rugians or Suebi would have intended to settle their situation with the new emperor and Avitus could have regained the control over these provinces based on a new foedus.

These Barbarians in Savia could have been the antiqui Barbari mentioned in Cassiodorus' Variae (Var. V.14.6), who were in all likelihood Germans (probably Suebi: cp. the consciously used variant of the province name

${ }^{23}$ STEIN 1914; SEECK 1921, 121-122; STEIN 1925, 354358; AlFöldi 1926, 93; SCHMIDT 1941, 261-262, 305-306; Mócsy 1962, 582; VÁRAdY 1969, 308, 331-332; Mócsy 1974, 350; Demougeot 1979, 516; Wozniak 1981, 351-354; Régészeti kézikönyv, 51; Fitz 1993, 1319, 1324; MACGEORGE 2002, 32-39; LotTer 2003, 17, McEvoy 2014, 257

${ }^{24}$ ALFÖLDI 1925; ALFÖLDI 1926, 101-104; SCHMIDT 1927; ENSSLIN 1927-1928; SCHMIDT 1941, 269-270; WoLFRAM 1979, 324325; SCHWARTZ 1992; A. KIss: Archeologia degli Ostrogoti in Pannonia (456-473). In: I goti. Ed.: V. Bierbrauer, O. von Hessen, E. Arslan. Milano 1994, 164-169 = Die Osthrogoten in Pannonien (456-473) aus archäologischer Sicht. ZalaiMúz 6 (1996) 87-91; LOTTER 2003, 104-106; Siebigs 2010, 474, 911-914, Exkurs XXV; GRAČANIN-ŠKRGULJA 2014.
${ }^{25}$ P. ANREITER: Die vorrömischen Namen Pannoniens. Archaeolingua SerMin 16. Budapest 2001, 257, 7; TH. VON GRIENBERGER: Ostgermanische Flussnamen bei Jordanes. Zeitschrift für deutsches Altertum und deutsche Literatur 55 (1914) 41-51, esp. 41-54.

${ }^{26}$ J. HARMATTA: Das Volk der Sadagaren. In: Analecta Orientalia memoriae Alexandri Csoma de Kőrös dicata. Hrsg.: L. Ligeti. Bibliotheca orientalis Hungarica 5. Budapest 1942 (1948) 17-28; J. HARMATTA: Studies in the History and Language of the Sarmatians. AASzeged 13. Minora opera 13. Szeged 1970, 56-57, 101, 107.

${ }^{27}$ Later, the Rugians intended to reach Italy through the Goths, i. e. on the Amber Route in Pannonia prima and Savia: Eug. v. Sev. 5. A passage of Sidonius Apollinaris and the vita Severini clearly show that the Goths ruled entire Pannonia prima as they attacked Norican territories: cf. Sid. Ap. II,377, v. Sev. 5, 17 (the siege of Tiburnia).

${ }^{28}$ Siebigs 2010, 912-913. 
Savia/Suavia (i.e. land of the Suebi) in Jordanes' works and in the early medieval manuscript tradition of several other works but it is clear that they were not identical (the Goths defeated the Suebi returning from Dalmatia by the Balaton and later, Thiudimer let them go home to Suavia, i.e. North of the Balaton) and the official province name could not be Suavia (cf. Cassiodorus used always the variant Savia: IV.49, V.14.6, 15, IX.8): Jord. Rom. 218, Get. LIII. 273, 274, Chron. min. I p. 539). These Barbarians recorded his earlier arrival even in the $6^{\text {th }}$ century (before the Ostrogoths' rule in Italy and Savia). ${ }^{29}$

It cannot be accidental that Marcianus who intended to normalize the situation in the Danubian provinces after Nedao concluded foedera with the winner Gepids (Jord. Get. L.264) ${ }^{30}$ and the Goths as well. It is striking that province Savia was not included in the treaty. That is why it can be supposed that the strategically important provinces remained (Noricum mediterraneum, Savia) under the control of Avitus.

Other contemporary events can show that the recovery of a part of Western Illyricum, i.e. Savia and Noricum mediterraneum/ripense cannot be excluded in this period:

1. Based on the treaty, the Goths were settled down into several provinces of West-Illyricum, i.e. in Pannonia prima, Valeria and Pannonia secunda but they avoided the provinces that were important strategically, i.e. Savia and Noricum mediterraneum.

2. Majorian collected a strong but ethnically complex army in 459 in order to regain the control over Gaul, Hispania and Africa (cf. Sid. Ap. Carm. V,472-479), but he had to fight against the revolting commander of his army, the Hun Tuldila (PLRE II, Tuldila) and his people (Carm. V,483-510). ${ }^{31}$ According to Sidonius Apollinaris' remark, they came from the direction of the Danube where he lost their lords, i.e. most probably the Huns who lost their king, Ellac in the battle of Nedao in 454 (Carm. V,485-487): $:^{32}$ quae nuper ab Histro / rettulit indomitum solito truculentior agmen / quod dominis per bella caret. In the description of Majorian's army the poet enumareted Huns, Suebi, Rugians, Ostrogoths, Sarmatians and Pannonians among other, fictitious or hardly known peoples. Barbarians who lived now in the territory of the former Roman province may have been called Pannonians $(\mathrm{Carm} . \mathrm{V}, 475) .^{33}$ Based on these two passages it seems highly likely that Majorian called these Danubian Barbarians based on foedus that could have been concluded by Avitus.

3. According to the account of the Fasti Vindobonienses Priores 577 that used the lost Consularia Italica written in Ravenna, Savaria was destroyed by an earthquake 9 September $456 .{ }^{34}$ The destruction had to be big enough to record it in the Fasti where only the activities of emperors (mainly Western), campaigns, Barbarian incursions or ecclesiastical events and interesting natural phenomena (eclipses, bigger earthquakes) were mentioned. In this case the event was placed among the records concerning Avitus' reign. Probably the same earthquake was mentioned in Eugippius' vita Severini in the region of Comagene (Tulln) in Noricum in a distance of approx. $100 \mathrm{~km}$ from Savaria (Eug. v. Sev. 2). ${ }^{35}$ On the other hand, the fact that news of the catastrophe reached Noricum and Northern Italy does not mean that Savaria and Western Pannonia I would have belonged to the Roman Empire, but it clearly shows the presence of provincial population in the former Roman colony.

Coming to conclusion, Avitus had no opportunity to command personally a military action or an imperial visit in Pannonia during his short reign. The iter can only be identified with his route from Arelate to Rome. There was hardly any chance to regain the control over the entire territory but a smaller military action or a legation can be supposed in the autumn of 455 and as a result of this Rome recovered the SW part of the dioecesis, namely

${ }^{29}$ J. ŠAŠEL: Antiqui Barbari. Zur Besiedlungsgeschichte Ostnoricums und Pannoniens im 5. und 6. Jahrhundert nach den Schriftquellen. In: Von der Spätantike zum frühen Mittelalter. Aktuelle Probleme in historischer und archäologischer Sicht. Hrsg.: J. Werner, E. Ewig. Vorträge und Forschungen 25. Sigmaringen 1979, 125-139 = Opera selecta. Ljubljana 1992, 746-760; H. CASTRITIUS: Antiqui Barbari. Zur Besiedlungsgeschichte Südostnorikums und Südpannoniens in der Spätantike (Ende des 4. bis Mitte des 6. Jahrhunderts n. Chr.). Frühmittelalterliche Studien 95 (1995) 72-85.

${ }^{30}$ C. Diculescu: Die Gepiden. Forschungen zur Geschichte Daziens im frühen Mittelalter und zur Vorgeschichte des rumänischen Volkes. Halle 1923, 101.

${ }^{31}$ LOYEN 1967, 78, n. 3; OPPEDISANO 2013, 262-263.

${ }^{32}$ Maenchen-Helfen 1973, 161-162.
${ }^{33}$ Loyen 1967, 78-79; R. W. MATHISEN: Catalogues of Barbarians in Late Antiquity. In: Romans, Barbarians, and the Transformation of the Roman World. Cultural Interaction and the Creation of Identity in Late Antiquity. Eds: R. W. Mathisen, D. Shanzer. Farnham-Burlington 2011, 17-32, esp. 26-27.

${ }^{34}$ A. RADNÓTI: Pannóniai városok élete a korai feudalizmusban [Urban life of Pannonian towns in the early Feudalism]. MTAK(II) 5 (1954) 503; BÓNA 1969, 281; BÓNA 1973, 310; F. LOTTER: Severinus von Noricum. Legende und historische Wirklichkeit. Monographien zur Geschichte des Mittelalters 12. Stuttgart 1976, 156-157; A. То́тн: A savariai földrengés [The earthquake in Savaria]. In: Firkák III. Fiatal római koros kutatók III. konferenciakötete. Ed.: P. Balázs. Szombathely 2014, 321-326.

${ }^{35}$ R. HüBL: Römisches Tulln. Das antike Comagenis. Tulln 2004,68

Acta Archaeologica Academiae Scientiarum Hungaricae 71, 2020 
province Savia and Noricum mediterraneum in order to confirm the security of Italy. Another possibility is that during his route a Barbarian legation from Pannonia met the emperor in Northern Italy and they concluded some kind of foedus that was interpreted by Sidonius Apollinaris as the recovery of Pannonia. The late Roman inner fort of Fenékpuszta and its destruction has nothing to do with Emperor Avitus.

\section{APPENDIX}

\section{The relevant sources}

Sidonius Apollinaris Carm. V.474 Hoc totum tua signa pavet; Bastarna, Suebus, Pannonius, Neurus, Chunus, Geta, Dacus, Halanus, Bellonotus, Rugus, Burgundio, Vesus, Alites,

Bisalta, Ostrogothus, Procrustes, Sarmata, Moschus

post aquilas venere tuas; tibi militat omnis

Caucasus et Scythicae potor Tanaiticus undae.

Fasti Vind. prior. 577 Chron. min. I p. 304 et eversa est Sabaria a terrae motu VII (scr. IV) idus Septembr. die Veneris

Eugippius v. Severini 2 Die autem tertio, cum sacrificii vespertini sollemnitas impleretur, facto subito terraemotu ita sunt barbari intrinsecus habitantes exterriti, ut portas sibi Romanos cogerent aperire velociter. Exeuntes igitur conciti diffugerunt, aestimantes se vicinorum hostium obsidione vallatos, auctoque terrore divinitus noctis errore confusi mutuis se gladiis conciderunt.

Hyd. Chron. 166 Chron. min. II p. 28 Per Avitum, qui a Romanis et evocatus et susceptus fuerat imperator, legati ad Marcianum pro unanimitate mittuntur imperii.

169 Marcianus et Avitus concordes principatu Romani utuntur imperii.

Jordanes Get. L.264 Nam Gepidi Hunnorum sibi sedes viribus vindicantes totius Daciae fines velut victores potiti nihil aliud a Romano imperio, nisi pacem et annua sollemnia, ut strenui viri, amica pactione postulaverunt. Quod et libens tunc annuit imperator et usque nunc consuetum donum gens ipsa a Romano suscipit principe. Gothi vero cernentes Gepidas Hunnorum sedes sibi defendere Hunnorumque populum suis antiquis sedibus occupare, maluerunt a Romano regno terras petere quam cum discrimine suo invadere alienas, accipientesque Pannoniam; quae in longo porrecta planitiae habet ab oriente Moesiam superiorem, a meridie Dalmatiam, ab occasu Noricum, a septentrione Danubium. Ornata patria civitatibus plurimis, quarum prima Syrmis, extrema Vindomina.

LII.268 Ergo, ut ad gentem, unde agimus, revertamur, id est Ostrogotharum, qui in Pannonia sub rege Valamir eiusque germani Thiudimer et Videmir morabantur, quamvis divisa loca, consilia tamen unita (nam Valamer inter Scarniungam et Aqua nigra fluvios, Thiudimer iuxta lacum Pelsois, Vidimer inter utrosque manebant), contigit ergo, ut Attilae fili contra Gothos quasi desertores dominationis suae, velut fugacia mancipia requirentes, venirent ignarisque aliis fratribus super Valamer solum inruerent.

270 Post tempus ergo non multum rex Valamir eiusque germani Thiudemir et Vidimir, consueta dum tardarent dona a principe Marciano, quae ad instar strenuae acciperent et pacis foedera custodirent, missa legatione ad imperatorem ...

LIII.272 Postquam ergo firma pax Gothorum cum Romanis effecta est, videntes Gothi non sibi sufficere ea quae ab imperatore acciperent simulque solitam cupientes ostentare virtutem, coeperunt vicinas gentes circumcirca praedari, primum contra Sadagis, qui interiorem Pannoniam possidebant, arma moventes. Quod ubi rex Hunnorum Dintzic filius Attilae cognovisset, collectis secum qui adhuc videbantur quamvis pauci eius tamen sub imperio remansisse Vltzinzures, Angisciros, Bittugures, Bardores, venientesque ad Basianam Pannoniae civitatem eamque circumvallans fines eius coepit praedare. 273 Quod conperto Gothi ibi, ubi erant, expeditionemque sol- 
ventes, quam contra Sadagis collegerant, in Hunnos convertunt et sic eos suis a finibus inglorios pepulerunt, ut iam ex illo tempore qui remanserunt Hunni et usque actenus Gothorum arma formident. Quiescente vero tandem Hunnorum gente a Gothis Hunumundus Suavorum dux dum ad depraedandas Dalmatias transit, armenta Gothorum in campis errantia depraedavit, quia Dalmatia Suaviae vicina erat nec a Pannonios fines multum distabat, praesertim ubi tunc Gothi residebant.

\section{REFERENCES}

ALFÖLDI 1924-1926

ALFÖLDI 1925

ANDERS 2010

ANDERSON 1936

BATTAGLIA 2017

BÓNA 1969

BÓNA 1973

BÓNA 1984

BÓNA 1991

BUGIANI 1909

BURGESS 1987

Demougeot 1979

ENSSLIN 1927-1928

FITZ 1993

FURBETTA 2014

FÜZES 1978

GRAČANIN 2006

GRAČANIN-ŠKRGULJA 2014

GRZYWACZWSKI 2014

HARRIES 1994

HEINRICH-TAMÁSKA-MÜLLER-STRAUB 2012

Hughes 2015

KISS 1999

LACAM 1986

LOTTER 2003

LOYEN 1967

MacGeorge 2002
= A. ALFöLDI: Der Untergang der Römerherrschaft in Pannonien. I-II. Berlin-Leipzig 1924-1926.

= A. Alföldi: A keleti gótok betelepülése Pannoniába [Settlement of the Eastern Goths in Pannonia]. In: Emlékkönyv Dr Gróf Klebelsberg Kuno negyedszázados kultúrpolitikai müködésének emlékére, születésének ötvenedik évfordulóján. Ed.: I. Lukinich. Budapest 1925, 121-125.

= F. ANDERS: Flavius Ricimer: Macht und Ohnmacht des weströmischen Heermeisters in der zweiten Hälfte des 5. Jahrhunderts. Europäische Hochschulschriften. 3.: Geschichte und ihre Hilfswissenschaften 1077. Frankfurt 2010.

= W. B. ANDERSON: Sidonius. Poems and Letters. I. Loeb classical library 296. Cambridge/Mass. 1936.

= P. BatTAglia: Sidonio Apollinare e il pangerico ad Avito. Tra doctrina, laus ed exempla. MA Thesis. Palermo 2017.

= I. BóNA: Bevezetés és kommentár Eugippius: Vita Sancti Severini első magyar fordításához [Introduction and Commentary to the First Hungarian Translation of Eugippius' Vita Sancti Severini]. Az Ókórtudományi Társaság kiadványai 7. Budapest 1969.

= I. BónA: Severiana. Acta AntHung 21 (1973) 281-338.

= I. BÓNA: A népvándorlás kor és a korai középkor története Magyarországon [A history of the Migration period and the Early Medieval Period in Hungary]. In: Magyarország története. I.: Előzmények és magyar történet 1242-ig. 1. Ed.: Gy. Székely. Budapest 1984, 265-373.

= I. BÓNA: Das Hunnenreich. Budapest 1991 .

= C. Bugiani: L'imperatore Avito. Pistoia 1909.

$=$ R. W. BuRGESS: The third regnal year of Eparchius Avitus: a reply. Classical Philology 82/4 (1987) 335-345.

= E. Demougeot: La formation de l'Europe et les invasions barbares de l'avènement de Dioclétien au début du VI siècle. Collection historique Paris 1979.

= W. Ensslin: Die Ostgoten in Pannonien. Byzantinisch-neugriechische Jb 6 (1927-1928) 146-159.

= J. FITZ: Die Verwaltung Pannoniens in der Römerzeit. I-IV. Budapest 1993-1995.

= L. FurbetTA: Il panegirico di Avito: note di metodo e nuovi risultati. In: Présence de Sidoine Apollinaire. Dir.: R. Poignault, A. Stoehr-Monjou. Caesarodunum-Présence de l'Antiquité 44-45. Clermont-Ferrand 2014, 73-85.

= M. FÜZES: A fenékpusztai gabonatemető. Egy római katonai expedíció növényi bizonyítékai [The 'grain cemetery' of Fenékpuszta. Plant evidence of a Roman military expeditiona]. ÉlTud 33 (1978) 787-790.

= H. GraČAnIN: The Huns and South Pannonia. Byzantinoslavica 64 (2006) 29-76.

= H. GraČAnIN-J. ŠKrgulja: The Ostrogoths in late antique Southern Pannonia. AAC 49 (2014) 165-205.

= J. GRZYWACZWSKI: Sidonius Apollinaris' pagan vision of ancient Roma bellatrix in Christian Rome. Studia Theologica Varsavensia 1 (2014) 179-194.

$=\mathrm{J}$. HARRIES: Sidonius Apollinaris and the Fall of Rome, AD 407-485. Oxford 1994.

= O. Heinrich-TAmásKa-R. Müller-P. Straub: A fenékpusztai római erőd évszázadai [The Roman Fortress of Fenékpuszta Through the Ages]. Zalaegerszeg 2012.

= I. Hughes: Patricians and Emperors. The Last Rulers of the Western Roman Empire. Barnsley 2015.

= A. KIss: Pannonien zur Zeit der Völkerwanderung - Ergebnisse und Probleme. In: L'Occident romain et l'Europe centrale au début de l'époque des Grandes Migrations. Dir.: J. Tejral, Ch. Pilet, M. Kazanski. Spisy Archeologického Ústavu AV ČR Brno 13. Brno 1999, 109-126.

= G. LACAM: Ricimer. Un Barbare au service de Rome. Paris 1986.

= F. LOTTER: Völkerverschiebungen im Ostalpen-Mitteldonau-Raum zwischen Antike und Mittelalter (365-600). GRA Ergänzungsband 39. Berlin-New York 2003.

= A. LOYEN: Recherches historiques sur les panégyriques de Sidoine Apollinaire. Sciences historiques et philologiques/Bibliothèque de l'École des hautes études 285. Studia historica 43. Roma 1967.

= P. MACGEORGE: Late Roman Warlords. Oxford classical monographs. Oxford 2002. 
MaEnChen-Helfen 1973

MATHISEN 1981

MATHISEN 1981

MATHISEN 1991

Matolcsi 1974

McEvor 2014

Mócsy 1962

Mócsy 1974

MÜLLER 1987

OPPEDISANO 2013

Régészeti kézikönyv

SÁGI 1970

SÁGI 1989

SCHMIDT 1927

SCHMIDT 1941

SCHWARZ 1992

SEECK 1896

SEECK 1919

SEECK 1921

SiEBIGS 2010

STEIN 1914

STEIN 1925

STEIN 1959

StRaub 2002

VÁRADY 1969

WATSON 1998

WIRTH 1999

WOLFRAM 1979

WOZNIAK 1981

ZECCHINI 1983
= O. J. MAENCHEN-HelfEN: The World of the Huns. Studies in their history and culture. Berkeley-Los Angeles-London 1973 = Die Welt der Hunnen: Eine Analyse ihrer historischen Dimension. WienKöln 1978.

= R. W. Mathisen: Avitus, Italy and the East. Byzantion 51 (1981) 232-247.

= R. W. Mathisen: The third regnal year of Eparchius Avitus. Classical Philology 8 (1985) 326-335

$=$ R. W. MATHISEN: The third regnal year of Eparchius Avitus: The interpretation of the evidence. In: R. W. Mathisen: Studies in the History, Literature and Society of Late Antiquity. Amsterdam 1991, 163-166.

= J. MATOLCSI: Állattani következtetés Fenékpuszta V. századi pusztulásának közelebbi időpontjára (Zoological conclusions for a more precise dating of the destruction of Fenékpuszta). ArchÉrt 101 (1974) 102-111.

= M. A. McEvoy: Child Emperor Rule in the Late Roman West, AD 367-455. Oxford classical monographs. Oxford 2014.

= A. Mócsy: Pannonia. In: PWRE IX. Supplementum. Stuttgart 1962, col. 515-776.

= A. Mócsy: Pannonia and Upper Moesia. A History of the Middle Danube Provinces of the Roman Empire. Provinces of the Roman Empire. London-Boston 1974.

= R. MÜLLER: Megjegyzések Fenékpuszta történetéhez (Bemerkungen zur Geschichte von Fenékpuszta). ZalaiMúz 1 (1987) 105-122.

= F. OPPEDISANO: L'impero d'occidente negli anni di Maioriano. Saggi di storia antica 36. Roma 2013.

= A. MócsY-J. Fitz (eds): Pannonia régészeti kézikönyve [An Archaeological Handbook of Pannonia]. Budapest 1990.

= K. SÁGI: Das Problem der pannonischen Romanisation im Spiegel der völkerwanderungszeitlichen Geschichte von Fenékpuszta. ActaAntHung 18 (1970) 147-196.

= K. SÁGI: Adatok a fenékpusztai eröd történetéhez (Über die Geschichte der Festung in Fenékpuszta). TVMK 1 (1989) 261-317.

= L. SCHMIDT: Die Ostgoten in Pannonien. UJb 6 (1927) 459-460.

= L. SchmidT: Geschichte der deutschen Stämme bis zum Ausgang der Völkerwanderung I.: Die Ostgermanen. München $1941^{2}$.

= A. SchwARZ: Die Goten in Pannonien und auf dem Balkan nach dem Ende des Hunnenreiches bis zum Italienzug Theoderichs des Großen. MIÖG 100 (1992) 50-83.

= O. SEECK: Avitus 5. In: PWRE II/2. Stuttgart 1896, col. 2395-2397.

= O. SEECK: Regesten der Kaisern und Päpste (311-476 n. Chr.). Vorarbeit zu einer Prosopographie der christlichen Kaiserzeit. Stuttgart 1919.

= O. SEECK: Geschichte des Untergangs der antiken Welt. I-VI. Berlin 1921 ${ }^{4}$.

= G. SiebigS: Kaiser Leo I. Das oströmische Reich in den ersten drei Jahren seiner Regierung (457-460 n. Chr.). Beiträge zur Altertumskunde 276. Berlin-New York 2010.

= E. STEIN: Der Verzicht der Galla Placidia auf die Präfektur Illyricum. Wiener Studien 36 (1914) 344-347.

= E. STEIN: Untersuchugen zur spätrömischen Verwaltungsgeschichte. Rheinisches Museum 74 (1925) 347-394 = Opera minora selecta. Amsterdam 1968, 71-127.

= E. STEIN: Histoire du Bas-Empire I. Paris 1959.

= P. StRauB: 5. századi tömegsírok Keszthely-Fenekpusztán (Massengräber aus dem 5. Jahrhundert in Keszthely-Fenékpuszta). MFMÉ 8 (2002) 177-200.

= L. VÁRADY: Das letzte Jahrhundert Pannoniens 376-476. Budapest 1969.

= L. WATSON: Representing the past, redefining the future: Sidonius Apollinaris Panegyrics of Avitus and Anthemius. In: The Propaganda of Power. The Role of Panegyric in Late Antiquity. Ed.: M. Whitby. Mnemosyne Suppl. 183. Leiden-Boston 1998, 177-198.

= G. WIRTH: Attila. Das Hunnenreich und Europa. Urban-Taschenbucher 467. Stuttgart-Berlin-Köln 1999.

= H. WolfRAm: Geschichte der Goten. Von den Anfängen bis zur Mitte des sechsten Jahrhunderts. Entwurf einer historischen Ethnographie. Frühe Völker. München 1979.

= F. E. WozniaK: East Rome, Ravenna and Western Illyricum: 454-536 A.D. Historia 30 (1981) 351-382.

= G. ZeCChInI: Aezio, l'ultima difesa dell Occidente romano. Monografie del centro ricerche di documentazione sull'antichità classica 8. Roma 1983.

Open Access. This is an open-access article distributed under the terms of the Creative Commons Attribution 4.0 International License (https:// creativecommons.org/licenses/by/4.0), which permits unrestricted use, distribution, and reproduction in any medium, provided the original author and source are credited, a link to the CC License is provided, and changes - if any - are indicated. (SID_1)

Acta Archaeologica Academiae Scientiarum Hungaricae 71, 2020 